\title{
Pemberdayaan Masyarakat dalam Mengenali Tanda-Tanda Bahaya pada Masa Kehamilan di Desa Penyengat Olak Kabupaten Muaro Jambi Tahun 2020
}

\author{
Herinawati $^{1}$, Diniyati ${ }^{2}$, Atika Fadhilah Danaz ${ }^{3}$, Iksaruddin $^{4}$ \\ 1,2,3 Jurusan Kebidanan Poltekkes Kemenkes Jambi \\ ${ }^{4}$ Jurusan Promkes Poltekkes Kemenkes Jambi \\ Email: herinawati_burhanuddin@yahoo.com
}

Published: 11/01/2021

\begin{abstract}
According to a report from the World Health Organization (WHO), maternal mortality generally occurs due to complications during and after pregnancy. As for the types of complications that cause the majority of maternal deaths, about $75 \%$ of the total maternal deaths are bleeding, infection, high blood pressure during pregnancy, complications of childbirth and unsafe abortion, these become very chronic considering the various causes of maternal death above are actually can be prevented by providing knowledge and understanding to pregnant women about the danger signs in pregnancy, if you experience that you immediately come to the health center or health personnel so that delays can be prevented, the mother immediately gets help which in turn can reduce cases of maternal death This activity aims to increase community empowerment in recognizing and preventing danger signs during pregnancy in Penyengat Olak Village, Muaro Jambi Regency in 2020. The targets are all pregnant women, husbands of pregnant women, community leaders, religious leaders and PKK mothers in Penyengat Olak Village. The method used is pre-test and post-test using a questionnaire, lectures and discussions. The speaker in this activity was a team of lecturers at the Poltekkes Ministry of Health Jambi, Department of Midwifery. The results of community service activities are the formation of community groups who are able to independently have knowledge and skills in recognizing danger signs during pregnancy in Penyengat Olak Village, Jambi Luar Kota District, Muaro Regency.
\end{abstract}

Keywords: danger sign, empowerment, pregnancy

\begin{abstract}
Abstrak
Menurut laporan dari World Health Organization (WHO) kematian ibu umumnya terjadi akibat komplikasi saat dan pasca kehamilan. Adapun jenis-jenis komplikasi yang menyebabkan mayoritas kasus kematian ibu sekitar $75 \%$ dari total kasus kematian ibu adalah perdarahan, infeksi, tekanan darah tinggi saat kehamilan, komplikasi persalinan dan aborsi yang tidak aman, hal ini menjadi sangat kronis mengingat berbagai penyebab kematian ibu diatas sebenarnya dapat dicegah dengan memberikan pengetahuan dan pemahaman kepada Ibu hamil mengenai tanda bahaya dalam kehamilan, jika Ibu mengalami segera datang ke puskesmas atau tenaga kesehatan sehingga keterlambatan dapat dicegah, ibu segera mendapat pertolongan yang pada akhirnya dapat menurunkan kasus kematian Ibu. Kegiatan ini bertujuan untuk Meningkatnya pemberdayaan masyarakat dalam mengenali dan pencegahan tanda gejala bahaya pada masa kehamilan di Desa Penyengat Olak Kabupaten Muaro Jambi Tahun 2020. Sasaran semua ibu hamil, suami ibu hamil, tokoh masyarakat, tokoh agama dan ibu-ibu PKK Desa Penyengat Olak. Metode yang digunakan adalah pre tes dan posttes menggunakan quesioner, ceramah dan diskusi. Pembicara dalam kegiatan ini adalah tim dosen Poltekkes Kemenkes Jambi Jurusan Kebidanan. Hasil Kegiatan pengabdian masyarakat terbentuknya kelompok masyarakat yang mampu secara mandiri memiliki pengetahuan dan ketrampilan dalam mengenali tanda-tanda bahaya pada masa kehamilan di Desa Penyengat Olak Kecamatan Jambi Luar Kota Kabupaten Muaro.
\end{abstract}

Kata Kunci: kehamilan, pemberdayaan, tanda bahaya 


\section{PENDAHULUAN}

Hingga tahun 2019 AKI Indonesia masih tetap tinggi, yaitu 305 per 100.000 kelahiran hidup. Padahal, target Angka Kematian Ibu (AKI) Indonesia pada tahun 2015 adalah 102 per 100.000 kelahiran hidup. AKI termasuk salah satu indikator penting dari derajat kesehatan masyarakat. AKI menggambarkan jumlah wanita yang meninggal dari suatu penyebab kematian terkait dengan gangguan kehamilan atau penanganan (tidak termasuk kecelakaan atau kasus insidental) selama kehamilan, melahirkan dan dalam masa nifas (42 hari setelah melahirkan) tanpa memperhitungkan lama kehamilannya per 100.000 kelahiran hidup.

Menurut laporan dari World Health Organization (WHO) kematian ibu umumnya terjadi akibat komplikasi saat dan pasca kehamilan. Adapun jenis-jenis komplikasi yang menyebabkan mayoritas kasus kematian ibu sekitar $75 \%$ dari total kasus kematian ibu adalah perdarahan, infeksi, tekanan darah tinggi saat kehamilan, komplikasi persalinan dan aborsi yang tidak aman

Faktor yang menyebabkan kematian ibu secara garis besar dapat dikelompokkan menjadi penyebab langsung dan tidak langsung. Penyebab langsung kematian ibu adalah faktor yang berhubungan dengan komplikasi kehamilan, persalinan dan nifas seperti perdarahan, pre eklampsia/ eklampsia, infeksi, persalinan macet dan abortus. Penyebab kematian tidak langsung kematian ibu adalah faktor yang memperberat keadaan ibu hamil seperti empat terlalu serta faktor yang mempersulit proses penanganan kedaruratan kehamilan, persalinan, dan nifas, seperti lebih kurang $65 \%$ kehamilan yang terjadi berhubungan dengan 4 terlalu, terlalu muda (usia kurang dari 20 tahun, terlalu tua (usia lebih dari 35 tahun), terlalu sering melahirkan (jarak kehamilan kurang dari 2 tahun), dan terlalu banyak (lebih dari 3 anak). Empat terlalu selain berpengaruh terhadap angka kematian ibu, juga mempunyai dampak terhadap kematian bayi dan pertumbuhan kesehatan bayi yang dilahirkan dan 3 terlambat yaitu terlambat mengenali kehamilan dalam situasi gawat, jauh dari fasilitas kesehatan, biaya, persepsi mengenai kualitas dan efektivitas dari pelayanan kesehatan. Terlambat kedua, dipengaruhi oleh lama pengangkutan, kondisi jalan dan biaya transportasi. Faktor yang mempengaruhi terlambat ketiga adalah terlambat mendapatkan pelayanan pertama kali di RS rujukan (Krisnadi, 2014).

Penyebab utama kematian ibu di Indonesia adalah perdarahan dan hipertensi. Hal ini menjadi sangat kronis mengingat berbagai penyebab kematian ibu diatas sebenarnya dapat dicegah dengan memberikan pengetahuan dan pemahaman kepada Ibu hamil mengenai tanda bahaya dalam kehamilan, jika Ibu mengalami segera datang ke puskesmas atau tenaga kesehatan sehingga keterlambatan dapat dicegah, ibu segera mendapat pertolongan yang pada akhirnya dapat menurunkan kasus kematian Ibu.

Kematian ibu juga disebabkan faktor dasar antara lain keterbatasan pengetahuan, taraf pendidikan, status sosial ekonomi, dan pengambilan keputusan di tingkat rumah tangga. Meningkatkan kesehatan ibu berarti meningkatkan terciptanya generasi penerus yang cerdas. Masih banyak ibu hamil yang tidak memperhatikan asupan gizi, sehingga anak yang dilahirkan berada dalam kondisi yang mengkhawatirkan. Untuk mengatasi kematian ibu dan kematian bayi diperlukan upaya inovatif dan kualitas pelayanan yang diberikan oleh tenaga kesehatan dan peningkatan pengetahuan ibu hamil mengenai asuhan dalam kehamilan.

Pemberdayaan masyarakat merupakan strategi dalam paradigma pembangunan yang bertumpu pada rakyat, Strategi ini menyadari pentingnya kapasitas masyarakat untuk meningkatkan kemadirian dan kekuatan internal, melalui kesanggupan 
untuk melakukan control internal atas sumber daya material dan non material.

Salah satu daerah yang menjadi mitra kegiatan pengabdian masyarakat adalah desa penyengat olak Kecamatan Jambi luar kota kabupaten Muaro Jambi, pada tahun 2019 ibu hamil yang berkunjung ke puskesmas penyengat olak ada yang terdekteksi resiko tinggi. Berdasarkan permasalahan diatas maka pengabdi tertarik melakukan pengabdian masyarakat dengan judul Pemberdayaan Masyarakat Dalam Mengenali TandaTanda Bahaya Pada Masa Kehamilan Di Desa Penyengat Olak Kecamatan Jambi Luar Kota Kabupaten Muaro Jambi Tahun 2020”.

\section{TARGET DAN LUARAN}

1. Target

Tokoh masyarakat, tokoh agama, kader, ibu PKK, seluruh ibu hamil, suami ibu hamil di Desa Penyengat Olak Kecamatan Jambi Luar Kota Kabupaten Muaro Jambi

2. Luaran

Terbentuknya kelompok masyarakat yang mampu secara mandiri memiliki pengetahuan dan ketrampilan dalam mengenali dan pencegahan tanda gejala bahaya pada masa kehamilan di desa penyengat olak kecamatan jambi luar kota kabupaten muaro.

\section{METODE PELAKSANAAN}

Waktu Pelaksanaan kegiatan pengabdian masyarakat dilaksanakan dari bulan Juli sampai dengan Oktober 2019, Didesa penyengat olak kecamatan jambi luar kota Kabupaten Muaro Jambi Tahun 2020. Metode yang digunakan dalam pengabdian ini adalah pre tes dan post tes menggunakan questioner, ceramah, diskusi, tanya jawab. Pada awal pertemuan dilakukan identifikasi permasalahan ibu hamil baik dengan metode wawancara maupun dengan pemeriksaan fisik. Metode wawancara dilaksanakan sebagai bentuk anamnesa untuk mengidentifikasi faktor resiko usia, riwayat kehamilan dan persalinan sebelumnya, jarak dengan anak terakhir. Proses wawancaara ini dilengkapi dengan melihat buku kesehatan ibu dan anak (Buka KIA). Pemeriksaan fisik dilakukan dengan mengukur tanda-tanda vital ibu, melihat konjungtiva, lingkaran lengan atas.

Serangkaian data ibu hamil tersebut disimpulkan sebagai masalah-masalah yang perlu diinformasikan dalam bentuk pendidikan kesehatan ibu hamil secara berkelanjutan untuk mencegah komplikasi dari faktor resiko yang ada. Metode ceramah digunakan pada saat pemberian informasi mengenali tanda- tanda bahaya pada masa kehamilan. Metode diskusi tanya jawab

Kerangka Pemecahan Masalah

\begin{tabular}{|l|l|l|}
\hline $\begin{array}{l}\text { Pemberdayaan } \\
\text { masyarakat dalam } \\
\text { mengenali tanda- } \\
\text { tanda bahaya pada } \\
\text { masa kehamilan }\end{array}$ & & $\begin{array}{l}\text { Penyuluhan } \\
\text { dan pelatihan }\end{array}$ \\
\hline
\end{tabular}

Realisasi Pemecahan Masalah

Metode Pelaksanaan

1. Peningkatan kesadaran masyarakat

Penyebarluasan informasi melalui papan pengumuman desa/kelurahan, penyuluhan, pemasangan poster, banner.

2. Pengembangan kemampuan masyarakat

3. Pengorganisasian masyarakat

4. Peningkatan upaya advokasi yang mendukung masyarakat memperjuangkan kepentingannya.

5. Penggalangan kemitraan

6. Peningkatan pemanfaatan potensi dan sumber daya

\section{HASIL DAN PEMBAHASAN}

Kegiatan pengabdian masyarakat dilakukan sebanyak 3 tahapan. Tahapan pertama dilakukan kegiatan survey 
ke lokasi pengabdian untuk memperoleh data awal permasalah yang ada diwilayah kegiatan, masih ditemukan ibu hamil dengan tanda-tanda bahaya kehamilan. Hasil kegiatan pengabdian pada masyarakat ini adalah penyuluhan tentang Pemberdayaan Masyarakat Dalam Mengenali Tanda-Tanda Bahaya Pada Masa Kehamilan di Desa Penyengat Olak Kecamatan Jambi Luar Kota Kabupaten Muaro Jambi Tahun 2020".

Kegiatan utama berupa penyuluhan dan demonstrasi yang dilakukan sebanyak 7 kali mulai dari bulan Juli sampai Oktober 2020. Tahapan kegiatan dilaksanakan sebagai berikut: Kegiatan yang dilakukan terdiri dari 1 kali survey awal, 5 kali kegiatan ceramah meliputi penyuluhan tentang tanda-tanda dan gejala bahaya pada masa kehamilan serta tanya jawab, lalu 1 kali kegiatan evaluasi.

a. Melaksanakan perijinan untuk dilakukan pengabdian masyarakat serta melakukan survey awal untuk melakukan identifikasi permasalahan pada ibu hamil.

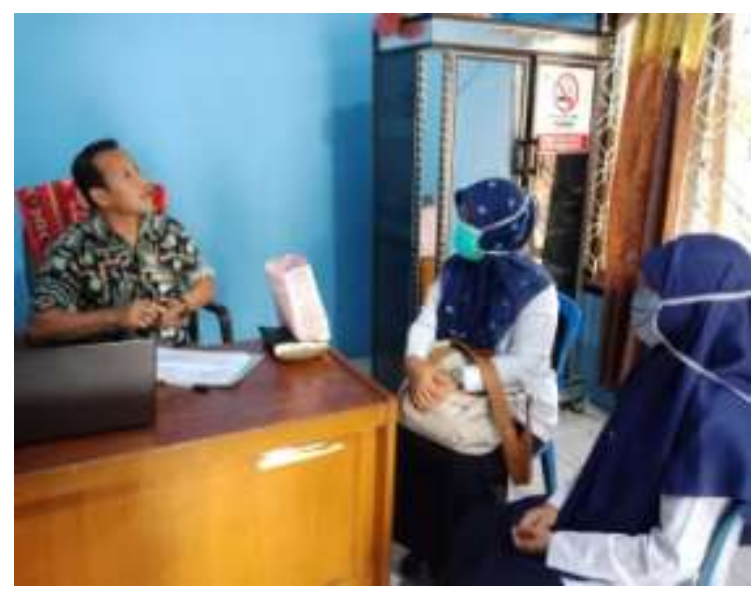

Gambar 1. Survey awal

b. Pemberian pendidikan kesehatan pada ibu hamil tentang kehamilan dengan faktor resiko sebanyak 5 kali pertemuan. Pemberian materi edukasi diberikan dengan menggunakan media power point, laptop dan infokus. Adapun materi yang disampaikan tentang pengertian kehamilan dengan faktor resiko dan akibatnya pada kehamilan dan persalinan maupun nifas.

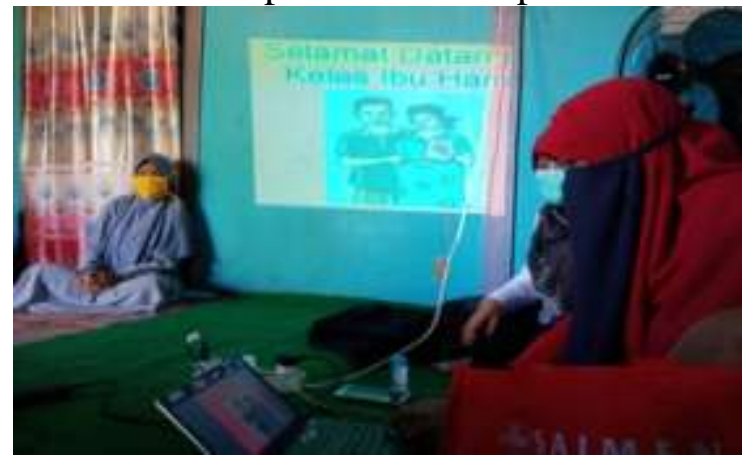

Gambar 2. Kegiatan Penyuluhan menggunakan infokus

Peserta yang hadir dalam kegiatan tersebut adalah kepala desa yang diwakili sekretaris desa, kepala puskesmas penyengat olak, tokoh masyarakat desa, kader posyandu dan bidan desa. Ibu hamil, suami ibu hamil. Penyuluhan dan demonstrasi ini dilakukan di rumah warga di Desa Penyengat Olak, dimana warga yang hadir melihat buku tentang tandatanda dan gejala bahaya pada kehamilan dan dapat melakukan tanya jawab dan diskusi mengenai masalah yang dialami selama kehamilan. Prosedur kegiatan penyuluhannya dimulai dari penjelasan umum dan perkenalan, sosialisasi manfaat, pelaksanaan pelatihan terhadap Kader (kesehatan), monitoring, evaluasi kegiatan dilakukan melalui form evaluasi peserta yaitu pre test dan post test lalu kesimpulan.

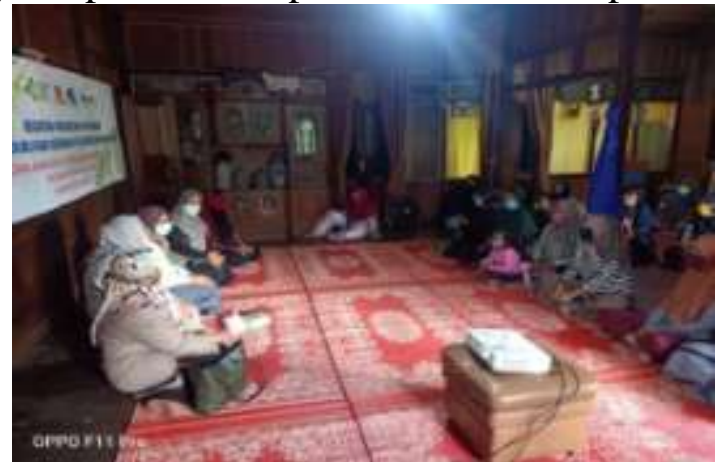

Gambar 3. Kegiatan penyuluhan terhadap ibu hamil

Dari hasil pendidikan kesehatan tentang faktor resiko pada kehamilan, beberapa ibu hamil aktif mengamati dan sangat antusias terhadap video tersebut. 
Beberapa ibu hamil aktif bertanya mengenai hal-hal yang belum paham.

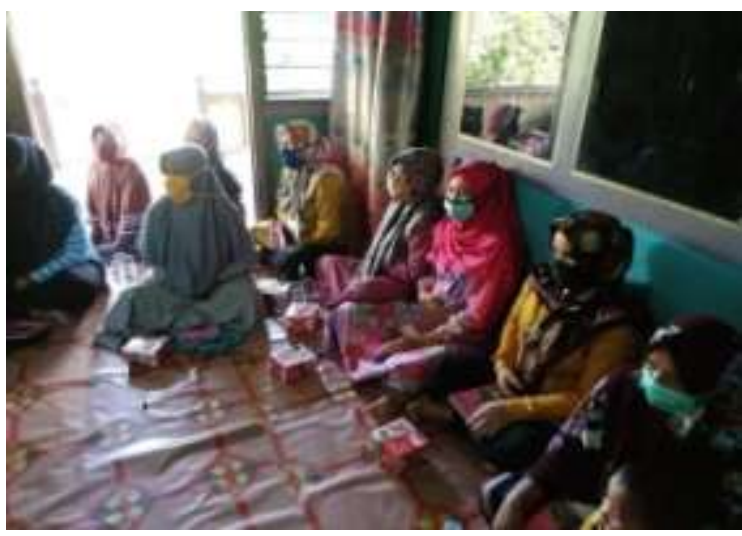

Gambar 4. Ibu hamil mengamati penjelasan penyaji

c. Setelah rangkaian kegiatan selesai dilakukan evaluasi untuk mengetahui kekurangan dan kelebihan terhadap kegiatan yang telah dilakukan guna merancang rencana tindak lanjut yang akan dilakukan setelah pengabdian masyarakat.

Adapun kendala yang dihadapi yaitu dikarenakan masa pandemi covid 19 maka kegiatan dilakukan dengan mengikuti protokol kesehatan yaitu mengecek suhu tubuh peserta pelatihan, peserta diwajibkan mencuci tangan, memakai masker/faceshield dan menjaga jarak dengan peserta lain.

\section{KESIMPULAN DAN SARAN}

\section{Kesimpulan}

Adapun kesimpulan hasil kegiatan pengabdian masyarakat yaitu pelaksanaan pemberdayaan masyarakat dalam mengenali dan pencegahan tanda-tanda dan gejala bahaya pada masa kehamilan di Desa Penyengat Olak Kecamatan Jambi Luar Kota Kabupaten Muaro Jambi Tahun 2020 sudah terlaksana dengan lancar dan mendapat respon yang baik dari kepala desa, tokoh masyarakat, kepala puskesmas penyengat olak, kader, Ibu PKK, ibu hamil dan suami ibu hamil. Kegiatan pemberdayaan masyarakat dalam mengenali dan pencegahan tanda-tanda dan gejala bahaya pada masa kehamilan di Desa Penyengat Olak Kecamatan Jambi Luar Kota Kabupaten Muaro Jambi Tahun 2020 dilaksanakan sebanyak 5 x. Kepala puskesmas dan penanggungjawab program KIA puskesmas penyengat olak akan melanjutkan kegiatan pemberdayaan masyarakat khususnya ibu hamil dalam mengenali tanda dan gejala bahaya selama kehamilan. Kepala desa akan menyiapkan sarana dan prasarana untuk tempat pertemuan kegiatan pemberdayaan masyarakat dalam mengenali dan pencegahan tanda-tanda dan gejala bahaya pada masa kehamilan.

\section{Saran}

Penyiapan

anggaran/dana pelaksanaan melalui pendanaan pemerintah daerah, swasta, dan donor yang terintegrasi. Dinas kesehatan dan puskesmas sebaiknya melakukan pemantauan dan evaluasi kegiatan di wilayah puskesmas.

\section{UCAPAN TERIMAKASIH}

Penulis mengucapkan terimakasih kepada Politeknik Kesehatan Kemenkes Jambi yang telah memberikan kesempatan untuk melaksanakan salah satu Tri Dharma Perguruan Tinggi yakni Pengabdian Kepada Masyarakat, kepada Puskesmas Penyengat Olak atas kesediaannya sebagai tempat pengabdian dan kepada ibu hamil yang telah berpartisipasi dalam kegiatan ini.

\section{DAFTAR PUSTAKA}

Bobak, I.M., Lowdermilk, D.L., \& Jensen, M.D. (2005). Buku ajar keperawatan maternitas. (Maria A. Wijayarini, Penerjemah) (Edisi 4). Jakarta: Penerbit Buku Kedokteran EGC. Buku asli diterbitkan tahun 1995.

Hailu, M., Gebremariam, A., \& Alemseged, F. (2010). Knowledge about obstetric danger sign among pregnant women in aleta wondo 
district, Sidama Zone, Southern Ethiophia. Ethiophia Journal Health Science, 20(1), 25-32.

Hanni Ummi, Marjati JK, Yulifah R. 2011. Asuhan Kebidanan pada Kehamialan Fisiologis,Jakarta : Salemba medika

Hutari Puji Astuti (2011) Hubungan Karakteristik Ibu Hamil Dengan Tingkat Pengetahuan Tentang Tanda Bahaya Pada Kehamilan Di Puskesmas Sidoharjo Kabupaten Sragen

Maryatun. 2016. Bahaya Kehamilan Pada Perkawinan Usia Muda. Stikes Aisyiyah Surakarta. INFOKES,
VOL. 1 NO. 1 Februari 2016 ISSN : $2086-2628$

Sasnitiari, Ni Nyoman Puspitasari, Dwi Anggraeni (2018) Hubungan Keikutsertaan Ibu Dalam Kelas Ibu Hamil Dengan Pengetahuan Dan Sikap Terhadap Tanda Bahaya Dalam Kehamilan Di Kota Bogor

Prawirhardjo . 2014. Ilmu Kebidanan. Jakarta : PT Bina Pustaka Sarwono Prawirohardjo

Vivi Budiarti, Rismaina Putri, Coryna Rizky Amelia (2018) Hubungan Karakteristik Ibu Dan Dukungan Suami Dengan Tingkat Pengetahuan Ibu Hamil Tentang Tanda Bahaya Kehamilan 